\title{
The Impact of Gender on Leadership Styles and Leadership Effectiveness
}

\author{
Basel Dwiri ${ }^{1}$, Kağan Okatan ${ }^{2}$ \\ ${ }^{1}$ Istanbul Aydin University, Institute of Graduated Students, Istanbul, Turkey \\ ORCID: 0000-0002-6455-6927 \\ ${ }^{2}$ Istanbul Aydin University, Istanbul, Turkey
}

\begin{abstract}
The purpose and aim of this research are to show and evaluate the impact of gender and the effectiveness (Decision making and relationships) between transformational leadership and transactional leadership respectively in real estate and construction companies. In addition, to bring to light whether male leaders are more effective than female leaders, or the opposite. Data were collected from 267 respondents in Istanbul, sample of Turkish firms based on the study model data were examined using the Statistical Package for the Social Sciences (SPSS) software by applying frequency distribution tables also bar charts of questionnaire (part A) and further correlation, R-Square, ANOVA and Regression Analysis for questionnaire (part B). Results show that the relationship between gender, transformational leadership and transactional leadership and their effectiveness (Decision making and Relationships) in the companies is positive. This study has analyzed through descriptive approach that was used to study about demographic profile of companies in Istanbul, and TRFL and TRSL items have been developed to test the hypothesis. Five-point Likert scale questionnaire and Seven-point Likert scale questionnaire has been adopted for data collection, the reliability statistics of all items was 0.887 for men and 0.915 for women which is excellent, in order to measure the relationship among variables correlation a test was used, regression analysis R-Square interpretation, ANOVA was used to show the impact of DM and R on TRFL and TRSL of the companies. Statistical analysis also showed results and suggestions for this model.
\end{abstract}

Keywords: Gender, Transformational Leadership, Transactional Leadership, Decision Making, Relationships, Turkey

\section{Introduction}

Throughout history, we have witnessed societies fall into anarchy because of the lack of proper leadership. Indeed, human beings are social creatures that live together and occupy different roles in society; some occupy the role of leaders, whereas others play the role of followers. It has been noticed that societies with good leaders often inspire their people to reach their full potential and grow therefore to be highly developed countries.

On the other hand, societies that lack good leaders often fall into chaos. This proves the importance of good leadership for any society to function, grow and eventually thrive. Similarly, but on a smaller scale, businesses and organizations need proper leaders and managers to operate successfully. This, of course, leads us to wonder about what it means to be a good leader. Some basic qualities associated with leadership include self-reliance, independence, assertiveness, ambition, and risk-taking. Although most leaders share these characteristics, different leaders tend to adopt different leadership styles because of various reasons.

One dimension that is said to affect leadership style among leaders, and their leadership effectiveness by extension is gender. Studies have shown that male and female leaders tend to operate and manage differently. Also, it goes without saying that women nowadays occupy more management positions in organizations and business than ever before. However, most leadership positions remain occupied by men. This, again, leads us to wonder about the impact of gender on both leadership styles and effectiveness within companies and organizations.

\subsection{Research Problem}

Many studies have been conducted to reveal the impact of gender on leadership styles and leadership effectiveness. Some of these studies found no correlation between these variables, whereas others concluded that gender impacts both leadership styles and effectiveness. Among the latter, there are researchers who found that males are more effective leaders than females, and researches who stated the opposite. Therefore, there's a clear disparity in the results of previous studies. In addition to this, most of the research conducted on this topic is done in western societies. In other words, there isn't a lot of data about the relationship of leadership and gender in countries like Turkey for example, and it will therefore be interesting to conduct a study about the impact of gender on leadership styles and effectiveness in Turkey.

\subsection{Significance of the Study}

There is a positive correlation between gender diversity and business success [1]. Also, a gender balance in senior management is positively associated with GDP growth. However, in almost half of the 13, 000 enterprises surveyed in 70 countries, female managers account for less than $33 \%$. [1]. The reason for this according to the ILO is that most enterprises require an "anytime, anywhere" availability which women supposedly cannot always offer due to their household and family responsibilities. A second reason, referred to as the "glass wall", describes how female managers are confined to roles such as human resources, finance, and administration, which are less strategic and less likely to lead to senior management positions. 
Therefore, this study will shed some light on the differences between male and female managers in terms of their preferred leadership styles and their leadership effectiveness. This will hopefully clarify if the prejudices against women, that are keeping them from occupying as many managerial positions as men, are indeed well founded, or if they are wrong assumptions that need to be corrected.

In conclusion, this study is important in that it might help organizations make better decisions regarding their recruiting of senior managers by understanding how men and women operate in leadership positions.

\subsection{Research objectives}

The objectives of this research are:

- To discover whether there are any differences between male and female leaders.

- To reveal the extent to which gender influences the choice of leadership styles.

- To discover which leadership styles are more likely to be associated with male leaders, and which are more likely to be associated with female leaders.

- To reveal the extent to which gender impacts leadership effectiveness.

- To bring to light whether male leaders are more effective than female leaders, or the opposite.

\subsection{Hypotheses of the Study}

Two styles of leadership were chosen, transformational leadership (TRFL) and transactional leadership (TRSL). Two types of leadership effectiveness were chosen, decision making (DM) and relationships (R). This results in 8 hypotheses:

- $\mathrm{H} 1=$ Gender (male) in transformational leadership has an impact on decision making.

- $\mathrm{H} 2=$ Gender (male) in transactional leadership has an impact on decision making.

- $\mathrm{H} 3=$ Gender (male) in transformational leadership has an impact on relationships.

- $\mathrm{H} 4=$ Gender (male) in transactional leadership has an impact on relationships.

- $\mathrm{H} 5=$ Gender (female) in transformational leadership has an impact on decision making.

- H6= Gender (female) in transactional leadership has an impact on decision making.

- $\mathrm{H} 7=$ Gender (female) in transformational leadership has an impact on relationships.

- $\mathrm{H} 8=$ Gender (female) in transactional leadership has an impact on relationships

\section{Review of the Literature}

There is ample evidence available on studies, that female leaders perform different leadership behaviors than male leaders $[2,3,4,5,6]$. Few studies in Germany found no gender disparities in leadership style and their efficacy [7]. In the other hand, there is a study concluded that men are more successful than woman leaders [8]. Analysis carried out before the late 1900s showed no substantial gap in the success of the actions of female and male leadership but in later years the significant researchers $[9,10,11]$ their own study has begun to be challenged and analysis doubt has been reported for further inquiries. This misunderstanding sparked a continuing discussion over the efficacy of the numerous leadership practices followed by male and female leaders. Businesses and corporate organizations with a high number of women in their senior management and leadership roles appear to have a greater positive effect on both financial success and operational quality [12]. Women are reported to be more participative and transformational in democracy than men [13] instead of their sexually stereotyped sense of security, genuine diplomacy, and contact [14].

\subsection{Gender}

Gender is derived etymologically from a word, genus, meaning 'kind' or 'shape' in Latin. Gender as a term applies to society which refers to the assigning of each sex with different traits, refers to what is normative or what is predicted which predicted in the actions of men and women. If male and female are the proper terms for sex, the corresponding terms for gender are masculine and feminine; therefore, the sum of masculinity or femininity contained in an individual is gender [15].In the sense of transformational leadership, a great deal of study has been undertaken to recognize the gaps between men and women. It has been shown that both have distinct leadership styles. Women respond to more democratic leadership and less autocratic than males [16]. Although men are task-oriented, women are people-oriented. Many surveys also suggest that women are better leaders in change than men are. Woman leaders score higher than male leaders in transformational activities [17]. Women prefer to use more democratic and transformational leadership styles than men [18].They will be more recognized and trusted than male transformational leaders as women display more positive actions compared to men [19, 20]. While several scholars have shown that women are more transformative than men, a few limitations make them less effective.

When women want to actively manipulate their subordinates, the responses towards them are hostile [6]. In addition, both masculine and feminine aspects are required for excellence in today's market setting [21].

\subsection{Gender and Leadership}

Gender roles are the accepted or predicted actions in social culture for men and women, implying what is commonly perceived to be the appropriate roles in each culture for men and women $[22,23,24,25]$.

Gender roles can be divided into two characters according to social role theory: the male agentic character, which shows steadiness, power, superiority, and self-confidence, and the female communal character, which shows emotion, benevolence, helpfulness, compassion, interpersonal sensitivity and gentleness [26, 27]. Leaders have historically been men, and women have had many challenges to becoming leaders [28]. Many experiments have shown that, based on the gender of leaders, subordinates are likely to display different psychological reactions and job habits and 
show different approval of female and male managers [29, 30].

In conventional patriarchal ideology, female leaders do not conform with the job demands and their success is judged to various criteria. For this cause, even though their success is similar, the assessment of male and female managers varies. In comparison, most female managers earn unfavourable assessments, primarily because of gender role expectations rather than their real abilities to work [29, 30]. Research on people's expectations of successful managers reveals that the "successful leadership image" is close to the "male image, " and that male managers are usually more likely than female managers to be viewed as successful and traditional managers [31, 32, 33, 34].

\subsection{Leadership Styles (LS)}

Leadership is an inherently abstract term [35]. Most of the topic of female's leadership centres on what has been called the issue of production and care for people [36]. Other approaches to conceptualize this dichotomy in leadership are by comparing questions over relationship-related roles [37]. Some of the evidence suggests that women leaders appear to be more relationship-oriented and male leaders more taskoriented [38, 39].

The transformational-transactional leadership paradigm has become a common theme in leadership literature in recent years [40, 41, 42, 43, 44, 45]. In comparison to task versus relationship-oriented leadership, the idea of transformational-transactional leadership is seen as a continuum that enables individuals to use transformational and transactional characteristics at the same time [41, 46].The definition of transformational and transactional leadership is presented below:

\subsubsection{Transformational Leadership (TRFL)}

Transformational leadership is a type of leadership that focuses on effecting revolutionary cultural change by contributing to that organization's vision [47, 48]. Transformation leaders rely on future needs and are more concerned about long-term concerns [49].It is a person entered style of leadership that facilitates subordinate creativity and workplace climate change [50]. Additionally, transformational leaders aim to inspire and empower their workforce to accomplish the organization's target [51]. When using this style, greater levels of intrinsic motivation, confidence, devotion, and loyalty from followers are required [52]. The leader must have good empathic abilities [51]. The leadership style of transformation has a strong positive effect on employee, community, and organizational results and a study reveal that followers are more inspired, active, and happy with transformational leaders [53]. According to [54] transformational leadership has four dimensions including:

\subsubsection{Idealized Influence (II)}

Divided into two terms: idealized attributed and behaviour. First, idealized influence attributed (IIA) relates to whether the leader is perceived as charismatic, strong, and optimistic or not and whether the followers choose to be identified with him/her. Secondly, idealized influence behaviour (IIB) involves communicating about his/her most significant ideals and convictions, stressing the common goal and purpose, and considering the ethical repercussions of his/her choices [55].

\subsubsection{Inspirational Motivation (IM)}

Inspirational motivation requires a leader who is confident and excited about building an enticing picture of the future, using emotional reasons [52]. The degree to which the leader articulates a message that communicates to supporters and encourages them.

\subsubsection{Intellectual Stimulation (IS)}

The degree to which the leader questions expectations, takes chances, and demands ideas from followers. Leaders with this characteristic stimulate their followers and promote imagination [56].

\subsubsection{Individualized Consideration (IC)}

Leaders handle workers as humans and not merely part of a community. This is achieved through sympathy, appreciation, and attention to the needs of workers, along with acknowledgment and celebration of accomplishments [53].

\subsubsection{Transactional Leadership (TRSL)}

Transactional leadership is focused on the use of legal authority within the organization's bureaucratic system [57]. The reality is that when they consider an offer of jobs, team members promise to follow their boss in all legitimate cases. The subordinates' continuity of this obedience is dependent on a bond of shared confidence and the leader's willingness to uphold agreements made. Good work will be rewarded, and poor performance will not, but the leader will intervene if things go bad [58]. This leadership style attempts to increase employee productivity by using extrinsic motivation [52].

Stable, predictable environments, a skilful transactional leader is likely to be effective. The leader satisfies the needs of supporters in exchange for performance that meets basic expectations [59].

Many scholars today conclude that transactional leadership can require the following styles of behaviour [56]:

\subsubsection{Contingent Reward (CR)}

The leader clarifies the job that needs to be done to change behavior. To obtain success as goals are met, the leader uses benefits or bonuses. It also applies to lead habits that tend to explain tasks and duties, then give incentives to followers. It's a relational and financial transaction if followers meet the desired results [60].

\subsubsection{Management-by-Exception Active (MBEA)}

The leader tracks the work undertaken and uses disciplinary measures to ensure that the work is done and meet agreed expectations. To control the behavior. MBEA's goal is to monitor followers and the processes [61]. Leaders are vigilant to ensure their followers achieve the regular objectives [41]. 


\subsubsection{Management-by-Exception Passive (MBEP)}

The leader uses corrections or discipline to control actions as a reaction to unacceptable results or to deviate from agreed expectations. Also, this aspect applies to leaders who interfere either when non-compliance has happened or after mistakes have already occurred, in other words, leaders sit back and wait for anything to go wrong before taking action [41].

\subsection{Leadership Effectiveness}

In the area of leadership, leadership effectiveness is an important term. More than five thousand meanings of the same is catalogued [62]. In a nutshell, the success of leadership depends primarily on the measurability of production and the fulfillment of mutual priorities. To deal with evolving expectations to develop good client, employee, and corporate relationships and to create effective productive relationships [63].

\subsubsection{Decision Making (DM)}

Decision-making is one of the factors that assess a leader 's efficacy. Gender research of leadership indicates that men and women display different differences of decision-making. Some of the differences concern the essence of the actions, the activities involved, and the creation of working relationships. Studies show that women rely on establishing and maintaining good working relationships to streamline processes for both junior and senior staff. On the other hand, men seldom concentrate on job relationships as they concentrate on outcomes [64].

\subsubsection{Relationships $(\mathrm{R})$}

Employees' views of relationships can be calculated according to their partnership philosophy. The following elements were used to assess organizational relationships [65]:

\subsubsection{Control Mutuality (CM)}

It applies to the degree to which parties' consent on who has the legitimate authority to affect each other. Although certain imbalances are normal, stable partnerships require some regulation for each entity and public.

\subsubsection{Trust (T)}

Trust is focused on the degree of confidence and desire of a party to open to the other party. For confidence, there are three dimensions. Integrity applies to the confidence that a corporation is honest and just. Dependability refers to the presumption that what it claims it will do will be achieved by an entity. Competence is the confidence that a corporation has the potential to do what it claims it can do.

\subsubsection{Commitment (C)}

This is the extent of which each individual trust and thinks that it is worth investing resources to sustain and promote the relationship. Continuing commitment, which refers to a particular course of action, and affective commitment, which is a relational disposition, are two aspects of commitment.

\subsubsection{Satisfaction (S)}

This refers to the degree to which each person feels favorable towards the other, so the relationship's optimistic expectations are improved. That of which the rewards outweigh the costs is a rewarding partnership.

\subsection{Conceptual Framework}

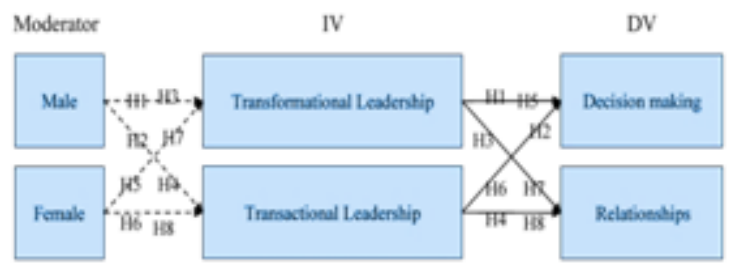

Figure 1: Conceptual Framework

\section{Research Methodology}

\subsection{Introduction}

This chapter is devoted solely to providing a concise sketch of research methods, means of data processing, sample size and analysis, SPSS software was used. The thesis questionnaire, its modes and essence. The research strategy is defined as: setting up a research model, studying literature on survey questions, building the best suitable survey from the alternatives, reaching and advising participants for the survey, collecting data, and assessing and evaluating data to validate the hypotheses [66].

\subsection{Target Population}

A crucial element in analysis is the selection of a sample [67]. Sampling decisions should concentrate on the target population of people; demographically, sampling decisions should concentrate on "who is the most informed person in the community or association and can provide reliable information" [68]. Various methods of choosing a sample are available, such as random sampling, hierarchical sampling, and stratified sampling [67]. One main aim of this research was to explore whether there are any gaps in divided institutions in Istanbul, Turkey, between male and female leadership styles.

\subsection{Sampling Size}

According to Istanbul Chamber of Commerce, the number of companies registered to trade registry is 667.409, and the number of registered companies is 440.319 .

In this research we took a sample of real estate and construction companies in Istanbul. Based on [URL1] Istanbul Chamber of Commerce, the number of real estate companies in Istanbul is 10.372 and the number of construction companies is 6.283 , that is mean the number of companies in Istanbul is 16.655 companies.

$$
\begin{aligned}
& \text { Sample size, } \mathrm{n}=\mathrm{N} \times \frac{\frac{Z^{2} \times p \times(1-p)}{e^{2}}}{\left[N-1+\frac{Z^{2} \times p \times(1-p)}{e^{2}}\right]} \\
& =16.655 \times \frac{\frac{1.645^{2} \times 0.5 \times(1-0.5)}{0.05^{2}}}{\left[16.655-1+\frac{1.645^{2} \times 0.5 \times(1-0.5)}{0.05^{2}}\right]}
\end{aligned}
$$

$=267$ responses

Where N (Population Size) $=16.655, \mathrm{Z}$ (Confidence level) $=1.645$, e (Margin of Error) $=0.05$, and $\mathrm{P}$ (Sample Proportion - uncertain $)=0.5$.

\section{Volume 10 Issue 1, January 2021




\section{International Journal of Science and Research (IJSR)

By using the above equation, the sample size required for this study is 267 responses.

\subsection{Sampling}

The sample will be collected from both real estate and construction companies in Istanbul from European and Anatolian sides. For the collection of data, simple and random sampling will be used. The data will be collected from 267 respondents of those companies.

\subsection{Research Methodology}

There are three types of methods to research: qualitative, quantitative, and mixed [69]. The quantitative approach is typically used where the purpose of the analysis is to find the relationship between variables [70]. This research uses a quantitative approach as the aim is to evaluate the relationships and decision-making of dependent variables and independent variables of leadership styles and gender. The obtained data was evaluated using version 22.0.0. of the Statistical Package for Social Sciences (SPSS). Moderator variables are male and female, independent variables used in this study are transformational leadership and transactional leadership whereas dependent variables are decision making and relationships. The leadership style is assessed by [71] Multifactor Leadership Questionnaire (MLQ). This instrument consisted of a model of transformational leadership and a style of transactional leadership. This instrument has been used by many researchers in their studies [72, 73, 74].

\subsection{Data Collection}

The most critical aspect of any research is data collection. This very important point lies in the outcome of every analysis. Most researchers do not stick to this stage very well, which is why, through their study, they struggle to achieve desired results. For that purpose, we have paid careful attention to this stage of our journey to keep the findings of the research intact and efficient for future use. We used an all-embracing questionnaire that discusses every aspect of our theses and theories to efficiently collect data. Researchers use primary data collection, which means that the entire data is gathered by the researcher through questionnaire with Likert type Scale. To obtain information from them, this questionnaire is spread among the respondents.

\section{Analysis}

\subsection{Demographic Discussion}

For this study, 267 respondents were contacted. The key feature of demographic discussion will be discussed below:

\subsubsection{Current Designation (job title)}

Table 1: Current Designation (job title)

\begin{tabular}{|c|c|c|}
\hline Position & Frequency & Percent \\
\hline Architect & 20 & $7.5 \%$ \\
\hline Designer & 25 & $9.4 \%$ \\
\hline Employee & 47 & $17.6 \%$ \\
\hline
\end{tabular}

\begin{tabular}{|c|c|c|}
\hline Engineer & 65 & $24.3 \%$ \\
\hline Manager & 23 & $8.6 \%$ \\
\hline Marketer & 30 & $11.2 \%$ \\
\hline Realtor & 38 & $14.2 \%$ \\
\hline Other & 19 & $7.1 \%$ \\
\hline Total & 267 & $100 \%$ \\
\hline
\end{tabular}

First, 7.5\% $(\mathrm{n}=20)$ of all respondents, they were Architect of different Turkish firms. Nearly 9.4\% $\quad(n=25)$ of all respondents were Designer, and around $17.6 \%(n=47)$ of all respondents were Employee at different Turkish company.

Engineers were the largest category among respondents, with $24.3 \%(n=65)$. Nearly $8.6 \%(n=23)$ of all respondents were Managers, and around $11.2 \%(\mathrm{n}=30)$ of all respondents were Marketers. Nearly $14.2 \%(n=38)$ of all respondents were Realtors. Nearly $7.1 \%(n=19)$ of all respondents were others (See Table 1).

\subsubsection{Highest level of formal education}

Table 2: The age of the company

\begin{tabular}{|c|c|c|}
\hline- & Frequency & Percent \\
\hline Secondary school & 8 & $3.0 \%$ \\
\hline Diploma & 26 & $9.7 \%$ \\
\hline Bachelor's degree & 143 & $53.6 \%$ \\
\hline Higher education & 90 & $33.7 \%$ \\
\hline Total & 267 & $100 \%$ \\
\hline
\end{tabular}

Over $33.7 \%(n=90)$ of respondents had a higher education degree. Bachelor's degree-holders were the largest category among respondents, with $53.6 \%(\mathrm{n}=143)$, but almost as many $(9.7 \%, \mathrm{n}=26)$ held a diploma degree. Secondary school certificate holders accounted for 3\% $(n=8)$ (See Table 2).

\subsubsection{The age of the company}

Table 3: The age of the company

\begin{tabular}{|c|c|c|}
\hline Years & Frequency & Percent \\
\hline Less than 2 years & 14 & $5.2 \%$ \\
\hline $2-5$ years & 44 & $16.5 \%$ \\
\hline $6-10$ years & 70 & $26.2 \%$ \\
\hline $11-20$ years & 91 & $34.1 \%$ \\
\hline More than 20 years & 48 & $18.0 \%$ \\
\hline Total & 267 & $100 \%$ \\
\hline
\end{tabular}

The respondents were working at a company that have over 20 years of $18 \%(n=48)$. The $11-20$ age group was in a clear majority with $34.1 \%(n=91)$ while the $6-10$ group were divided at $26.2 \%(n=70)$, and the $2-5$ group were almost equally divided at $16.5 \%(n=44)$ and for less than 2 years group were divided at $5.2 \%(n=14)$ respectively (See Table 3).

\subsubsection{Total number of employees in the organization}

Table 4: Total number of employees in the organization

\begin{tabular}{|c|c|c|}
\hline Employees & Frequency & Percent \\
\hline Less than 20 & 28 & $10.5 \%$ \\
\hline $20-99$ & 71 & $26.6 \%$ \\
\hline $100-199$ & 78 & $29.2 \%$ \\
\hline $200-1000$ & 71 & $26.6 \%$ \\
\hline More than 1000 & 19 & $7.1 \%$ \\
\hline Total & 267 & $100 \%$ \\
\hline
\end{tabular}

Volume 10 Issue 1, January 2021 


\section{International Journal of Science and Research (IJSR) \\ ISSN: 2319-7064 \\ SJIF (2019): 7.583}

First, $7.1 \% \quad(n=19)$ of the respondents were working at a company that have more than 1000 employees. 26.6\% $(n=71)$ working at a company that have between 200 to 1000 employees. $29.2 \%(n=78)$ of the respondents were working at a company that have between 100 to 199 employees. $26.6 \%(n=71)$ were working at a company that have between 20 to 99 employees and $10.5 \%(n=28)$ were working at a company that have less than 20 employees (See Table 4).

\subsubsection{Period of employment in the organization}

Table 5: Period of employment in the organization

\begin{tabular}{|c|c|c|}
\hline Years & Frequency & Percent \\
\hline 5 years or less & 154 & $57.7 \%$ \\
\hline 6-10 years & 95 & $35.6 \%$ \\
\hline 11-15 years & 13 & $4.9 \%$ \\
\hline $16-20$ years & 1 & $0.4 \%$ \\
\hline $21+$ & 4 & $1.5 \%$ \\
\hline Total & 267 & $100 \%$ \\
\hline
\end{tabular}

Nearly half the employees had worked for only five years or less in the company $(57.7 \% \mathrm{n}=154)$. Those with $6-10$ years' experience came in second place with $35.6 \%(\mathrm{n}=95)$. The 11-15-year group accounted for $4.9 \%(n=13)$, and only $0.4 \%$ $(n=1)$ had worked in the company for 16-20 years, and the +21 years group accounted for $1.5 \%(n=4)$ (See Table 5).

\subsubsection{Age}

Table 6: Age

\begin{tabular}{|c|c|c|}
\hline Years & Frequency & Percent \\
\hline $16-24$ & 64 & $24 \%$ \\
\hline $25-34$ & 102 & $38.2 \%$ \\
\hline $35-44$ & 78 & $29.2 \%$ \\
\hline $45-54$ & 22 & $8.2 \%$ \\
\hline 55 and above & 1 & $0.4 \%$ \\
\hline Total & 267 & $100 \%$ \\
\hline
\end{tabular}

One of the respondents were over 55. The 25-34 age group was in a clear majority with $38.2 \%(n=102)$ while the $16-24$ group were divided at $24 \%(n=64)$, and the $35-44$ group were almost equally divided at $29.2 \%(n=78)$ and the $45-54$ group were divided at $8.2 \%(n=22)$ respectively (See Table $6)$.

\subsubsection{Gender}

Table 7: Gender

\begin{tabular}{|c|c|c|}
\hline Gender & Frequency & Percent \\
\hline Male & 158 & $59.2 \%$ \\
\hline Female & 109 & $40.8 \%$ \\
\hline Total & 267 & $100 \%$ \\
\hline
\end{tabular}

In this study, a total of 267 respondents participated, of whom $59.2 \%(n=158)$ were male, and $40.8(n=109)$ were female, the numbers of men and women in the research are close, it gives the study a positive point to be more realistic (See Table 7).

\subsubsection{Marital Status}

Table 8: Marital Status

\begin{tabular}{|c|c|c|}
\hline Marital Status & Frequency & Percent \\
\hline Married & 103 & $38.6 \%$ \\
\hline Single & 155 & $58.1 \%$ \\
\hline Divorced & 7 & $2.6 \%$ \\
\hline Widowed & 2 & $0.7 \%$ \\
\hline Total & 267 & $100 \%$ \\
\hline
\end{tabular}

Two thirds of respondents $(58.1 \%, \mathrm{n}=155)$ were single and almost one third $(38.6 \%, \mathrm{n}=103)$ were married. Only a tiny percentage $(2.6 \%, \mathrm{n}=7)$ were divorced and $(0.7 \%, \mathrm{n}=2)$ were widowed (See Table 8).

\subsection{Factor Analysis}

The Kaiser-Meyer - Olkin (KMO) Test is an indicator of the suitability of your data for factor analysis. The test measures the sampling adequacy for each parameter in the system and for the model. The statistics are a measure of the variance ratio between variables that might be typical and common [75].

Table 9: KMO Result Explanation based on [76]

\begin{tabular}{|c|c|}
\hline Value & Status - Result \\
\hline Between 0.00 to 0.49 & Unacceptable \\
\hline Between 0.50 to 0.59 & Miserable \\
\hline Between 0.60 to 0.69 & Mediocre \\
\hline Between 0.70 to 0.79 & Middling \\
\hline Between 0.80 to 0.89 & Meritorious \\
\hline Between 0.90 to 1.00 & Marvelous \\
\hline
\end{tabular}

4.2.1. Factor Analysis (KMO) for independent variables (Transformational and Transactional Leadership) (For Male)

Table 10: Factor Analysis - KMO Test result for independent variables (For Male)

\begin{tabular}{|c|c|c|}
\hline \multicolumn{3}{|c|}{ KMO and Bartlett's Test } \\
\hline Kaiser-Meyer-Olkin Measure of Sampling Adequacy. & .816 \\
\hline \multirow{2}{*}{$\begin{array}{c}\text { Bartlett's Test of } \\
\text { Sphericity }\end{array}$} & Approx. Chi-Square & 833.779 \\
\cline { 2 - 3 } & $\mathrm{df}$ & 120 \\
\cline { 2 - 3 } & Sig. & .000 \\
\hline
\end{tabular}

Based on the above table, the KMO for the independent variables in this study is 0.816 . That mean our values of sample is Meritorious and acceptable.

\subsubsection{Factor Analysis (Rotated Component Matrix) for independent variables (Transformational and Transactional Leadership) (For Male)}

Table 11: Factor Analysis - Rotated Component Matrix Test result for independent variables (For Male)

\begin{tabular}{|c|c|c|}
\hline \multicolumn{3}{|l|}{ Rotated Component Matrix ${ }^{\mathrm{a}}$} \\
\hline & \multicolumn{2}{|c|}{ Component } \\
\hline & 1 & 2 \\
\hline $\begin{array}{l}\text { LS.TRFL.IIA1 My manager instils pride in me for being associated with him/her and behaves in ways that build my } \\
\text { confidence }\end{array}$ & .679 & \\
\hline LS.TRFL.IIA2 My manager moves beyond self-interest for the good of the group and displays a sense of power and & .752 & \\
\hline
\end{tabular}

\section{Volume 10 Issue 1, January 2021 www.ijsr.net}




\begin{tabular}{|c|c|c|}
\hline confidence & & \\
\hline LS.TRFL.IIB1 My manager emphasizes the value of getting a collective sense of mission and a strong sense of purpose & .558 & \\
\hline LS.TRFL.IIB2 My manager talks about our fundamental interests and beliefs & 671 & \\
\hline LS.TRFL.IM1 My manager talks optimistically and excitedly about the future & .670 & \\
\hline LS.TRFL.IM2 My manager shows a clear vision of the future and expresses confidence that goals will be achieved & 620 & \\
\hline $\begin{array}{c}\text { LS.TRFL.IS1 My manager seeks to get me look from many different angles and differing perspectives when solving } \\
\text { problems }\end{array}$ & .516 & \\
\hline LS.TRFL.IS2 My manager suggests new ways of looking at how to complete assignments & .538 & \\
\hline LS.TRFL.IC1 My manager spends time teach and coach to help me developing my strengths & .534 & \\
\hline $\begin{array}{c}\text { LS.TRFL.IC2 My manager treats me as an individual rather than just a member of a group because he knows that I have } \\
\text { different needs and abilities from others }\end{array}$ & & \\
\hline $\begin{array}{l}\text { LS.TRSL.CR2 My manager discusses in specific terms who is responsible for achieving performance targets and what one } \\
\text { expects to receive when performance goals are achieved }\end{array}$ & & $\begin{array}{c}.80 \\
7 \\
\end{array}$ \\
\hline $\begin{array}{l}\text { LS.TRSL.CR1 My manager provides me with assistance in exchange for my contributions and he expresses satisfaction } \\
\text { when I meet expectations }\end{array}$ & & $\begin{array}{c}.79 \\
0\end{array}$ \\
\hline $\begin{array}{l}\text { LS.TRSL.MBEA1 My manager keeps track of all mistakes and focuses attention on irregularities, exceptions, and } \\
\text { deviations from standards and concentrates his/her full attention on dealing with them all }\end{array}$ & & \begin{tabular}{|cc}
.73 \\
9
\end{tabular} \\
\hline LS.TRSL.MBEA2 My manager directs my attention toward failures to meet standards & & $\begin{array}{c}.83 \\
6\end{array}$ \\
\hline $\begin{array}{l}\begin{array}{l}\text { LS.TRSL.MBEP1 My manager fails to interfere until problems become serious and demonstrates that problems must } \\
\text { become chronic before taking action }\end{array} \\
\end{array}$ & & \\
\hline LS.TRSL.MBEP2 My manager shows that he/she is a firm believer in -if it ain`t broke, don't fix it & & \\
\hline \multicolumn{3}{|l|}{$\begin{array}{l}\text { Extraction Method: Principal Component Analysis. } \\
\text { Rotation Method: Varimax with Kaiser Normalization. }\end{array}$} \\
\hline a. Rotation converged in 3 iterations. & & \\
\hline
\end{tabular}

Based on table 11, the researcher founds the below about independent variables:

- Transformational leadership (TRFL), its grouped in one group (factor). That is mean the Transformational Leadership will be as it is. Transactional leadership (TRSL), its grouped in one group (factor). That is mean the Transactional Leadership will be as it is.

- The question LS.TRFL.IC2 in Transformational Leadership, its discarded because of its factor can't be grouped.

- The questions LS.TRSL.MBEP1 and LS.TRSL.MBEP2 in Transactional Leadership, its discarded because of its factor can't be grouped.

\subsubsection{Factor Analysis (KMO) for dependent variables} (Decision making and Relationships) (For Male)

Table 12: Factor Analysis - KMO Test result for dependent variables (For Male)

KMO and Bartlett's Test

\begin{tabular}{|c|c|c|}
\hline \multicolumn{3}{|c|}{ KMO and Bartlett's Test } \\
\hline Kaiser-Meyer-Olkin Measure of Sampling Adequacy & .886 \\
\cline { 2 - 3 } $\begin{array}{c}\text { Bartlett's Test of } \\
\text { Sphericity }\end{array}$ & Approx. Chi-Square & 851.016 \\
\cline { 2 - 3 } & df & 105 \\
\cline { 2 - 3 } & Sig. & .000 \\
\hline
\end{tabular}

Based on the above table, the KMO for dependent variables in this study is 0.886 . That mean our values of sample is Meritorious and acceptable.

\subsubsection{Factor Analysis (Rotated Component Matrix) for dependent variables (Decision making and Relationships) (For Male)}

Table 13: Factor Analysis - Rotated Component Matrix Test result for dependent variables (For Male) Rotated Component Matrix $^{\mathrm{a}}$

\begin{tabular}{|c|c|c|}
\hline \multicolumn{3}{|l|}{ Rotated Component Matrix ${ }^{\mathrm{a}}$} \\
\hline & \multicolumn{2}{|c|}{ Component } \\
\hline & 1 & 2 \\
\hline DM1 My manager makes his decisions in line with the company's goals to achieve the desired targets. & & .774 \\
\hline DM2 My manager chooses the easiest alternative to practical application when making his decisions. & & .697 \\
\hline $\begin{array}{l}\text { DM3 Employees do not face major obstacles in implementing the decisions my manager takes because he takes it } \\
\text { considering the workers' capabilities. }\end{array}$ & & .736 \\
\hline DM4 My manager takes his decisions in the appropriate time to face urgent problems. & & .628 \\
\hline $\begin{array}{c}\text { DM5 The decisions my manager made are accepted by the relevant workers because he consults workers when making } \\
\text { decisions. }\end{array}$ & & .733 \\
\hline R.CM1 Employees at the company are attentive to each other's sayings. & .569 & \\
\hline R.CM2 Employees at the company believe my views and opinions are legitimate. & .583 & \\
\hline R.CM3 Workers at the company have a tendency to throw their weight around when dealing with people like me. & & \\
\hline R.T1 Employees at the company treat me fairly and justly. & .766 & \\
\hline R.T2 Whenever managers make a significant decision, I know that they're going to be concerned about me. & 639 & \\
\hline R.T3 Employees at the company can be relied on to keep their promises. & 698 & \\
\hline $\begin{array}{l}\text { R.C1 There's a long-lasting bond between the employees working at the company and me and wanting to keep a } \\
\text { relationship with me. }\end{array}$ & 666 & \\
\hline R.S1 I'm very happy and pleased with the company. & .703 & \\
\hline R.S2 I have a mutual relationship with the employees at the company. & .714 & \\
\hline
\end{tabular}

Volume 10 Issue 1, January 2021 www.ijsr.net

Licensed Under Creative Commons Attribution CC BY 
Based on table 13, the researcher founds the below about dependent variables:

- Decision making (DM), its grouped in one group (factor). That is mean the Decision making will be as it is. Relationships (R), its grouped in one group (factor). That is mean the Relationships will be as it is.

- The question R.CM3 in relationships, its discarded because of its factor can't be grouped.

\subsubsection{Factor Analysis (KMO) for independent variables (Transformational and Transactional Leadership) (For Female)}

Table 14: Factor Analysis - KMO Test result for independent variables (For Female) KMO and Bartlett's Test \begin{tabular}{|l|r|}
\hline Kaiser-Meyer-Olkin Measure of Sampling Adequacy. & .815 \\
\hline
\end{tabular} Bartlett's Test of Sphericity

\begin{tabular}{|c|c|}
\hline Approx. Chi-Square & 721.532 \\
\hline $\mathrm{df}$ & 120 \\
\hline Sig. & .000 \\
\hline
\end{tabular}

Based on the above table, the KMO for dependent variables in this study is 0.815 . That mean our values of sample is Meritorious and acceptable.

\subsubsection{Factor Analysis (Rotated Component Matrix) for independent variables (Transformational and Transactional Leadership) (For Female)}

Table 15: Factor Analysis - Rotated Component Matrix Test result for independent variables (For Female)

\begin{tabular}{|c|c|c|}
\hline \multicolumn{3}{|l|}{ Rotated Component Matrix ${ }^{a}$} \\
\hline & \multicolumn{2}{|c|}{ Component } \\
\hline & 1 & 2 \\
\hline LS.TRFL.IIA1 My manager instils pride in me for being associated with him/her and behaves in ways that build my confidence & & .828 \\
\hline LS.TRFL.IIA2 My manager moves beyond self-interest for the good of the group and displays a sense of power and confidence & & .603 \\
\hline LS.TRFL.IIB1 My manager emphasizes the value of getting a collective sense of mission and a strong sense of purpose & .555 & \\
\hline LS.TRFL.IIB2 My manager talks about our fundamental interests and beliefs & & .541 \\
\hline LS.TRFL.IM1 My manager talks optimistically and excitedly about the future & & .656 \\
\hline LS.TRFL.IM2 My manager shows a clear vision of the future and expresses confidence that goals will be achieved & & .509 \\
\hline \begin{tabular}{|l|l|l} 
LS.TRFL.IS1 My manager seeks to get me look from many different angles and differing perspectives when solving problems \\
\end{tabular} & .599 & \\
\hline LS.TRFL.IS2 My manager suggests new ways of looking at how to complete assignments & .550 & \\
\hline LS.TRFL.IC1 My manager spends time teach and coach to help me developing my strengths & & .754 \\
\hline $\begin{array}{l}\text { LS.TRFL.IC2 My manager treats me as an individual rather than just a member of a group because he knows that I have } \\
\text { different needs and abilities from others }\end{array}$ & .536 & \\
\hline $\begin{array}{l}\text { LS.TRSL.CR2 My manager discusses in specific terms who is responsible for achieving performance targets and what one } \\
\text { expects to receive when performance goals are achieved }\end{array}$ & .747 & \\
\hline \begin{tabular}{|c} 
LS.TRSL.CR1 My manager provides me with assistance in exchange for my contributions and he expresses satisfaction when I \\
meet expectations
\end{tabular} & .740 & \\
\hline $\begin{array}{l}\text { LS.TRSL.MBEA1 My manager keeps track of all mistakes and focuses attention on irregularities, exceptions, and deviations } \\
\text { from standards and concentrates his/her full attention on dealing with them all }\end{array}$ & .674 & \\
\hline LS.TRSL.MBEA2 My manager directs my attention toward failures to meet standards & .728 & \\
\hline $\begin{array}{l}\text { LS.TRSL.MBEP1 My manager fails to interfere until problems become serious and demonstrates that problems must become } \\
\text { chronic before taking action }\end{array}$ & & \\
\hline LS.TRSL.MBEP2 My manager shows that he/she is a firm believer in -if it ain't broke, don't fix it & & \\
\hline $\begin{array}{l}\text { Extraction Method: Principal Component Analysis. } \\
\text { Rotation Method: Varimax with Kaiser Normalization. }\end{array}$ & & \\
\hline
\end{tabular}

Based on table 18, the researcher founds the below about independent variables:

- Transformational leadership (TRSL), its grouped in two groups (factors). That is mean the Transformational Leadership will be Transformational LeadershipDevelopment and Transformational Leadershipdirective. Transactional leadership (TRSL), its grouped in one group (factor). That is mean the Transactional Leadership will be as it is.
- The questions LS.TRFL.IIA1, LS.TRFL.IIA2, LS.TRFL.IIB2， LS.TRFL.IM1， LS.TRFL.IM2 and LS.TRFL.IC1 are related to Transformational Leadership- Development (TRFL-Development).

- The questions LS.TRFL.IIB1, LS.TRFL.IS1, LS.TRFL.IS2 and LS.TRFL.IC2 are related to Transformational Leadership- Directive (TRFLDirective). 
- The question LS.TRFL.IC2 in Transformational Leadership, its discarded because of its factor can't be grouped.

- The questions LS.TRSL.MBEP1 and LS.TRSL.MBEP2 in Transactional Leadership, its discarded because of its factor can't be grouped.

4.2.7. Factor Analysis (KMO) for dependent variables (Decision making and Relationships) (For Female)

Table 16: Factor Analysis - KMO Test result for dependent variables (For Female) KMO and Bartlett's Test

\begin{tabular}{|c|c|c|}
\hline \multicolumn{2}{|c|}{ Kaiser-Meyer-Olkin Measure of Sampling Adequacy. } & .806 \\
\hline \multirow{3}{*}{ Bartlett's Test of Sphericity } & Approx. Chi-Square & 587.228 \\
\hline & $\mathrm{df}$ & 105 \\
\hline & Sig. & .000 \\
\hline
\end{tabular}

Based on the above table, the KMO for dependent variables in this study is 0.806 . That mean our values of sample is Meritorious and acceptable.

4.2.8. Factor Analysis (Rotated Component Matrix) for dependent variables (Decision making and Relationships) (For Female)

Table 17: Factor Analysis - Rotated Component Matrix Test result for dependent variables (For Female)

\begin{tabular}{|c|c|c|}
\hline \multicolumn{3}{|l|}{ Rotated Component Matrix ${ }^{\mathrm{a}}$} \\
\hline & \multicolumn{2}{|c|}{ Component } \\
\hline & 1 & 2 \\
\hline \multicolumn{3}{|l|}{ DM1 My manager makes his decisions in line with the company's goals to achieve the desired targets. } \\
\hline DM2 My manager chooses the easiest alternative to practical application when making his decisions. & & .804 \\
\hline $\begin{array}{l}\text { DM3 Employees do not face major obstacles in implementing the decisions my manager takes because he takes it } \\
\text { considering the workers' capabilities. }\end{array}$ & & .712 \\
\hline DM4 My manager takes his decisions in the appropriate time to face urgent problems. & & .772 \\
\hline $\begin{array}{l}\text { DM5 The decisions my manager made are accepted by the relevant workers because he consults workers when making } \\
\text { decisions. }\end{array}$ & & .678 \\
\hline \multicolumn{3}{|l|}{ R.CM1 Employees at the company are attentive to each other's sayings. } \\
\hline R.CM2 Employees at the company believe my views and opinions are legitimate. & .510 & \\
\hline \multicolumn{3}{|l|}{ R.CM3 Workers at the company have a tendency to throw their weight around when dealing with people like me. } \\
\hline R.T1 Employees at the company treat me fairly and justly. & .732 & \\
\hline R.T2 Whenever managers make a significant decision, I know that they're going to be concerned about me. & .748 & \\
\hline R.T3 Employees at the company can be relied on to keep their promises. & 627 & \\
\hline $\begin{array}{l}\text { R.C1 There's a long-lasting bond between the employees working at the company and me and wanting to keep a } \\
\text { relationship with me. }\end{array}$ & .783 & \\
\hline R.S1 I'm very happy and pleased with the company. & .729 & \\
\hline R.S2 I have a mutual relationship with the employees at the company. & .669 & \\
\hline R.S3 The majority of employees are happy with their interactions with the company. & .721 & \\
\hline $\begin{array}{l}\text { Extraction Method: Principal Component Analysis. } \\
\text { Rotation Method: Varimax with Kaiser Normalization. }{ }^{\text {a }}\end{array}$ & & \\
\hline
\end{tabular}

Based on table 20, the researcher founds the below about dependent variables:

- Decision making, its grouped in one group (factor). That is mean the Decision making will be as it is. Relationships, its grouped in one group (factor). That is mean the Relationships will be as it is.

- The question DM1 in decision making, its discarded because of its factor can't be grouped.

- The questions R.CM1 and R.CM3 in relationships, its discarded because of its factor can't be grouped.

\subsection{Reliability Test}

\subsubsection{Reliability Test for Male}

Table 18: Reliability Test for Male

\begin{tabular}{|c|c|c|}
\hline Variable & Cronbach's Alpha & N of Items \\
\hline Transformational Leadership & 0.826 & 9 \\
\hline Transactional Leadership & 0.829 & 4 \\
\hline
\end{tabular}

Volume 10 Issue 1, January 2021 www.ijsr.net

Licensed Under Creative Commons Attribution CC BY

\begin{tabular}{|c|c|c|}
\hline Decision Making & 0.804 & 5 \\
\hline Relationships & 0.866 & 9 \\
\hline Overall Items & 0.887 & 27 \\
\hline
\end{tabular}

- Reliability test of items has checked through Cronbach's alpha of overall items and it is $88.7 \%$ which is excellent it means we can say that items which we have used in this research that are valid and acceptable.

- Reliability test of items has checked through Cronbach's alpha of Transformational Leadership (TRFL) items and it is $82.6 \%$ which is excellent it means we can say that Transformational Leadership items which we have used in this research that are valid and acceptable.

- Reliability test of items has checked through Cronbach's alpha of Transactional Leadership (TRSL) items and it is $82.9 \%$ which is also excellent indicator that means we can say that Transactional Leadership 


\section{International Journal of Science and Research (IJSR)

items which we have used in this research that are valid and acceptable.

- Reliability test of items has checked through Cronbach's alpha of Decision-Making (DM) items and it is $80.4 \%$ which is also excellent indicator that means we can say that Decision Making items which we have used in this research that are valid and acceptable.

- Reliability test of items has checked through Cronbach's alpha of Relationships (R) items and it is $86.6 \%$ which is also excellent indicator that means we can say that Relationships items which we have used in this research that are valid and acceptable.

\subsubsection{Reliability Test for Female}

Table 19: Reliability Test for Female

\begin{tabular}{|c|c|c|}
\hline Variable & Cronbach's Alpha & N of Items \\
\hline Transformational Leadership & 0.869 & 10 \\
\hline Transactional Leadership & 0.794 & 4 \\
\hline Decision Making & 0.783 & 4 \\
\hline Relationships & 0.858 & 8 \\
\hline Overall Items & 0.915 & 26 \\
\hline
\end{tabular}

- Reliability test of items has checked through Cronbach's alpha of overall items and it is $91.5 \%$ which is excellent it means we can say that items which we have used in this research that are valid and acceptable.

- Reliability test of items has checked through Cronbach's alpha of Transformational Leadership (TRFL) items and it is $86.9 \%$ which is excellent it means we can say that Transformational Leadership items which we have used in this research that are valid and acceptable.

- Reliability test of items has checked through Cronbach's alpha of Transactional Leadership (TRSL) items and it is $79.4 \%$ which is also excellent indicator that means we can say that Transactional Leadership items which we have used in this research that are valid and acceptable.

- Reliability test of items has checked through Cronbach's alpha of Decision-Making (DM) items and it is $78.3 \%$ which is also excellent indicator that means we can say that Decision Making items which we have used in this research that are valid and acceptable.

- Reliability test of items has checked through Cronbach's alpha of Relationships (R) items and it is $85.8 \%$ which is also excellent indicator that means we can say that Relationships items which we have used in this research that are valid and acceptable.

\subsection{Correlation Analysis}

Abbreviations for the below tables:

Pearson Correlation (PC), Sig. (2-tailed) (Sig), Transformational Leadership (TRFL), Transactional Leadership (TRSL), Decision Making (DM), Relationships (R), Transformational Leadership Development (TRFLDe), Transformational Leadership Directive (TRFLDi).

\subsubsection{Correlation Analysis for Male}

Table 20: Correlation Analysis for Male

\begin{tabular}{|c|c|c|c|c|c|}
\hline \multicolumn{6}{|c|}{ Correlations } \\
\hline & & TRFL & TRSL & DM & $\mathrm{R}$ \\
\hline \multirow{3}{*}{ TRFL } & $\mathrm{PC}$ & 1 & $.396^{* *}$ & $.509^{* *}$ & $.352^{* *}$ \\
\hline & Sig & & .000 & .000 & .000 \\
\hline & $\mathrm{N}$ & 158 & 158 & 158 & 158 \\
\hline \multirow{3}{*}{ TRSL } & $\mathrm{PC}$ & $396^{* *}$ & 1 & $201^{*}$ & .014 \\
\hline & Sig & .000 & & .011 & .860 \\
\hline & $\mathrm{N}$ & 158 & 158 & 158 & 158 \\
\hline \multirow{3}{*}{ DM } & $\mathrm{PC}$ & $.509^{* * *}$ & $.201^{*}$ & 1 & $.504^{* *}$ \\
\hline & Sig & .000 & .011 & & .000 \\
\hline & $\mathrm{N}$ & 158 & 158 & 158 & 158 \\
\hline \multirow{3}{*}{$\mathrm{R}$} & $\mathrm{PC}$ & $.352^{* * *}$ & .014 & $.504^{* *}$ & 1 \\
\hline & Sig & .000 & .860 & .000 & \\
\hline & $\mathrm{N}$ & 158 & 158 & 158 & 158 \\
\hline \multicolumn{6}{|c|}{$\begin{array}{l}\text { **. Correlation is significant at the } 0.01 \text { level. } \\
* \text { * Correlation is significant at the } 0.05 \text { level. }\end{array}$} \\
\hline
\end{tabular}

\subsubsection{Correlation Analysis for Female}

Table 21: Correlation Analysis for Female

\begin{tabular}{|c|c|c|c|c|c|c|}
\hline \multicolumn{7}{|c|}{ Correlations } \\
\hline & & TRFLDe & TRFLDi & TRSL & DM & $\mathrm{R}$ \\
\hline \multirow{3}{*}{ TRFLDe } & $\mathrm{PC}$ & 1 & $.686^{* *}$ & $.472^{\text {** }}$ & $.474^{* * *}$ & $.196^{*}$ \\
\hline & Sig & & .000 & .000 & .000 & .041 \\
\hline & $\mathrm{N}$ & 109 & 109 & 109 & 109 & 109 \\
\hline \multirow{3}{*}{ TRFLDi } & $\mathrm{PC}$ & $.686^{\text {*** }}$ & 1 & $.633^{* * *}$ & $.681^{\text {** }}$ & $.445^{* * *}$ \\
\hline & Sig & .000 & & .000 & .000 & .000 \\
\hline & $\mathrm{N}$ & 109 & 109 & 109 & 109 & 109 \\
\hline \multirow{3}{*}{ TRSL } & $\mathrm{PC}$ & $.472^{* * *}$ & $.633^{* * *}$ & 1 & $.595^{* *}$ & $.473^{* *}$ \\
\hline & Sig & .000 & .000 & & .000 & .000 \\
\hline & $\mathrm{N}$ & 109 & 109 & 109 & 109 & 109 \\
\hline \multirow{3}{*}{$\mathrm{DM}$} & PC & $.474^{* *}$ & $.681^{* * *}$ & $.595^{* * *}$ & 1 & $.344^{* *}$ \\
\hline & Sig & .000 & .000 & .000 & & .000 \\
\hline & $\mathrm{N}$ & 109 & 109 & 109 & 109 & 109 \\
\hline \multirow{3}{*}{$\mathrm{R}$} & $\mathrm{PC}$ & $.196^{*}$ & $.445^{* *}$ & $.473^{* * *}$ & $.344^{* * *}$ & 1 \\
\hline & Sig & .041 & .000 & .000 & .000 & \\
\hline & $\mathrm{N}$ & 109 & 109 & 109 & $\begin{array}{l}109 \\
\end{array}$ & $\begin{array}{l}109 \\
\end{array}$ \\
\hline
\end{tabular}

This thesis contains 8 main hypotheses. These hypotheses are newer and are linked with each other to form a new hypothesis which is "Is there an impact of gender on leadership styles and leadership effectiveness?" Now, to assess their validity, the researcher underwent a test of these variables. According to [77], Researchers perform correlation tests to investigate if these elements are related to each other and whether their mixture is true or not. The main variables of this thesis are Transformational Leadership and Transactional Leadership, and depending variables were Decision making and Relationships. The test is that how these variables are linked with one another.

The correlation values range from -1.00 to +1.00 .

\subsection{Regression Analysis}

\subsubsection{Regression Analysis for Male}




\subsubsection{1. $\mathbf{R}^{2}$ for Decision Making (For Male)}

Table 22: $\mathrm{R}^{2}$ for Decision Making (For Male)

\begin{tabular}{|c|c|c|c|c|}
\hline \multicolumn{5}{|c|}{ Model Summary } \\
\hline Model & $\mathrm{R}$ & $\mathrm{R}^{2}$ & $\begin{array}{c}\text { Adjusted R } \\
\text { Square }\end{array}$ & $\begin{array}{c}\text { Std. Error of } \\
\text { the Estimate }\end{array}$ \\
\hline 1 & $.509^{\mathrm{a}}$ & .259 & .249 & .59262 \\
\hline \multicolumn{5}{|c}{ a. Predictors: (Constant), TRSL, TRFL } \\
\end{tabular}

$\mathrm{R}^{2}$ is 0.259 that means using Transformational Leadership (TRFL) and Transactional Leadership (TRSL) can explained by $25.9 \%$ variations of variation in Decision Making of the companies.

\subsubsection{ANOVA for Decision Making (For Male)}

Table 23: ANOVA for Decision Making (For Male)

\begin{tabular}{|c|c|c|c|c|c|}
\hline \multicolumn{6}{|c|}{ ANOVA $^{a}$} \\
\hline Model & $\begin{array}{c}\text { Sum of } \\
\text { Squares }\end{array}$ & $\mathrm{df}$ & $\begin{array}{c}\text { Mean } \\
\text { Square }\end{array}$ & $\mathrm{F}$ & Sig. \\
\hline Regression & 19.022 & 2 & 9.511 & 27.082 & $.000^{\mathrm{b}}$ \\
\hline Residual & 54.435 & 155 & .351 & & \\
\hline Total & 73.457 & 157 & & & \\
\hline & $\begin{array}{r}\text { a. De } \\
\text { edicto }\end{array}$ & ns & $\begin{array}{l}\text { le: } 1 \\
\text { TRS } \\
\end{array}$ & & \\
\hline
\end{tabular}

Above table (ANOVA) showing the significance value is 0.000 and it is below that 0.05 it means that Regression analysis also supported hypotheses of this research.

\subsubsection{Beta Interpretations for Decision Making (For Male)}

Table 24: Co-efficient of Betas for Decision Making (For Male)

\begin{tabular}{|c|c|c|c|c|c|}
\hline \multicolumn{7}{|c|}{ Coefficients $^{\mathbf{a}}$} \\
\hline \multirow{2}{*}{ Model } & Unstandardized & Standardized & \multirow{2}{*}{ Sig. } \\
\cline { 2 - 5 } & $\mathrm{B}$ & Std. Error & Beta & & \\
\hline Constant & 1.560 & .331 & & 4.713 & .000 \\
\hline TRFL & .605 & .089 & .509 & 6.761 & .000 \\
\hline TRSL & -.001 & .056 & -.001 & -.012 & .991 \\
\hline \multicolumn{7}{|c|}{ a. Dependent Variable: DM } \\
\hline
\end{tabular}

Based on the above table, the researcher finds the below:

- If the leader will adopt TRFL style (Transformational Leadership), then DM (Decision Making) will be increase by $60.5 \%$.

- If the leader will adopt TRSL style (Transactional Leadership), then DM (Decision Making) will be decrease by $0.1 \%$.

4.5.1.4. $R^{2}$ for Relationships (For Male)

Table 25: $\mathrm{R}^{2}$ for Relationships (For Male)

\begin{tabular}{|c|c|c|c|c|}
\hline \multicolumn{5}{|c|}{ Model Summary } \\
\hline Model & $\mathrm{R}$ & $\mathrm{R}^{2}$ & $\begin{array}{c}\text { Adjusted } \mathrm{R} \\
\text { Square }\end{array}$ & $\begin{array}{c}\text { Std. Error of the } \\
\text { Estimate }\end{array}$ \\
\hline 1 & $.378^{\mathrm{a}}$ & .143 & .132 & .59000 \\
\hline \multicolumn{5}{|r|}{ a. Predictors: (Constant), TRSL, TRFL } \\
\hline
\end{tabular}

$\mathrm{R}^{2}$ is 0.143 that means using Transformational Leadership (TRFL) and Transactional Leadership (TRSL) can explained by $14.3 \%$ variations of variation in Relationships of the companies.
4.5.1.5. ANOVA for Relationships (For Male)

Table 26: ANOVA for Relationships (For Male)

\begin{tabular}{|c|c|c|c|c|c|}
\hline \multicolumn{7}{|c|}{ ANOVA $^{\text {a }}$} \\
\hline Model & $\begin{array}{c}\text { Sum of } \\
\text { Squares }\end{array}$ & df & $\begin{array}{c}\text { Mean } \\
\text { Square }\end{array}$ & F & Sig. \\
\hline Regression & 8.994 & 2 & 4.497 & 12.919 & $.000^{\mathrm{b}}$ \\
\hline Residual & 53.956 & 155 & .348 & & \\
\hline Total & 62.950 & 157 & & & \\
\hline \multicolumn{7}{|c|}{ a. Dependent Variable: R } \\
b. Predictors: (Constant), TRSL, TRFL \\
\hline
\end{tabular}

Above table (ANOVA) showing the significance value is 0.000 and it is below that 0.05 it means that Regression analysis also supported hypotheses of this research.

\subsubsection{Beta Interpretations for Relationships (For Male)}

Table 27: Co-efficient of Betas for Relationships (For Male)

\begin{tabular}{|c|c|c|c|c|c|}
\hline \multicolumn{7}{|c|}{ Coefficients $^{\mathrm{a}}$} \\
\hline \multirow{2}{*}{ Model } & Unstandardized & Standardized & \multirow{2}{*}{$\mathrm{t}$} & Sig. \\
\cline { 2 - 5 } & $\mathrm{B}$ & $\begin{array}{c}\text { Std. } \\
\text { Error }\end{array}$ & Beta & & \\
\hline Constant & 4.573 & .330 & & 13.876 & .000 \\
\hline TRFL & .452 & .089 & .411 & 5.080 & .000 \\
\hline TRSL & -.102 & .055 & -.149 & -1.839 & .068 \\
\hline \multicolumn{7}{|c|}{ a. Dependent Variable: $\mathrm{R}$} \\
\hline
\end{tabular}

Based on the above table, the researcher finds the below:

- If the leader will adopt TRFL style (Transformational leadership), then $\mathrm{R}$ (Relationships) will be increase by $45.2 \%$.

- If the leader will adopt TRSL style (Transactional Leadership), then $\mathrm{R}$ (Relationships) will be decrease by $10.2 \%$.

\subsubsection{Regression Analysis for Female}

\subsubsection{1. $\mathbf{R}^{2}$ for Decision Making (For Female)}

Table 28: $\mathrm{R}^{2}$ for Decision Making (For Female)

\begin{tabular}{|c|c|c|c|c|}
\hline \multicolumn{5}{|c|}{ Model Summary } \\
\hline Model & $\mathrm{R}$ & $\mathrm{R}^{2}$ & $\begin{array}{c}\text { Adjusted R } \\
\text { Square }\end{array}$ & $\begin{array}{c}\text { Std. Error of } \\
\text { the Estimate }\end{array}$ \\
\hline 1 & $.713^{\mathrm{a}}$ & .509 & .495 & .54724 \\
\hline \multicolumn{4}{|c|}{ a. Predictors: (Constant), TRSL, TRFL.De, TRFL.Di } \\
\hline
\end{tabular}

$\mathrm{R}^{2}$ is 0.509 that means using Transactional Leadership (TRSL), Transformational leadership-Development (TRFL.De), Transformational Leadership-Directive (TRFL.Di) can explained by $50.9 \%$ variations of variation in Decision making of the companies.

\subsubsection{ANOVA for Decision Making (For Female)}

Table 29: ANOVA for Decision Making (For Female)

\begin{tabular}{|c|c|c|c|c|c|}
\hline \multicolumn{7}{|c|}{ ANOVA $^{\mathrm{a}}$} \\
\hline Model & Sum of Squares & df & Mean Square & F & Sig. \\
\hline Regression & 32.576 & 3 & 10.859 & 36.259 & $.000^{\mathrm{b}}$ \\
\hline Residual & 31.445 & 105 & .299 & & \\
\hline Total & 64.021 & 108 & & & \\
\hline \multicolumn{7}{|c|}{ a. Dependent Variable: DM } \\
b. Predictors: (Constant), TRSL, TRFL.De, TRFL.Di \\
\hline
\end{tabular}




\section{International Journal of Science and Research (IJSR)

Above table (ANOVA) showing the significance value is 0.000 and it is below that 0.05 it means that Regression analysis also supported hypotheses of this research.

\subsubsection{Beta Interpretations for Decision Making (For Female}

Table 30: Beta Interpretations for Decision Making (For Female)

\begin{tabular}{|c|c|c|c|c|c|}
\hline \multicolumn{7}{|c|}{ Coefficients $^{\mathbf{a}}$} \\
\hline \multirow{2}{*}{ Model } & Unstandardized & Standardized & \multirow{2}{*}{ Sig. } & \multirow{2}{*}{ Sig. } \\
\cline { 2 - 5 } & B & Std. Error & Beta & & \\
\hline Constant & 1.066 & .355 & & 3.001 & .003 \\
\hline TRFLDe & -.009 & .115 & -.007 & -.078 & .938 \\
\hline TRFLDi & .492 & .103 & .513 & 4.784 & .000 \\
\hline TRSL & .249 & .081 & .274 & 3.090 & .003 \\
\hline \multicolumn{7}{|c|}{ a. Dependent Variable: DM } \\
\hline
\end{tabular}

Based on the above table, the researcher finds the below:

- If the leader will adopt TRFL.Destyle (Transformational Leadership-Development), then DM (Decision Making) will be decrease by $0.9 \%$.

- If the leader will adopt TRFL.Di style (Transformational Leadership-Directive), then DM (Decision Making) will be increase by $49.2 \%$.

- If the leader will adopt TRSL style (Transactional Leadership), then DM (Decision Making) will be increase by $24.9 \%$.

\subsubsection{4. $\mathbf{R}^{2}$ for Relationships (For Female)}

Table 31: $\mathrm{R}^{2}$ for Relationships (For Female)

\begin{tabular}{|c|c|c|c|c|}
\hline \multicolumn{5}{|c|}{ Model Summary } \\
\hline Model & $\mathrm{R}$ & $\mathrm{R}^{2}$ & $\begin{array}{c}\text { Adjusted } \mathrm{R} \\
\text { Square }\end{array}$ & $\begin{array}{c}\text { Std. Error of the } \\
\text { Estimate }\end{array}$ \\
\hline 1 & $.535^{\mathrm{a}}$ & .287 & .266 & .53459 \\
\hline \multicolumn{4}{|r|}{ a. Predictors: (Constant), TRSL, TRFL.De, TRFL.Di } \\
\hline
\end{tabular}

$\mathrm{R}^{2}$ is 0.287 that means using Transactional Leadership (TRSL), Transformational leadership-Development (TRFL.De), Transformational Leadership-Directive (TRFL.Di) can explained by $28.7 \%$ variations of variation in Relationships of the companies.

\subsubsection{ANOVA for Relationships (For Female)}

Table 32: ANOVA for Relationships (For Female)

\begin{tabular}{|c|c|c|c|c|c|}
\hline \multicolumn{7}{|c|}{ ANOVA $^{\text {a }}$} \\
\hline Model & Sum of Squares & df & Mean Square & F & Sig. \\
\hline Regression & 12.060 & 3 & 4.020 & 14.067 & $.000^{\mathrm{b}}$ \\
\hline Residual & 30.007 & 105 & .286 & & \\
\hline Total & 42.068 & 108 & & & \\
\hline \multicolumn{7}{|c|}{ a. Dependent Variable: R } \\
b. Predictors: (Constant), TRSL, TRFL.De, TRFL.Di \\
\hline
\end{tabular}

Above table (ANOVA) showing the significance value is 0.000 and it is below that 0.05 it means that Regression analysis also supported hypotheses of this research.
4.5.2.6. Beta Interpretations for Relationships (For Female)

Table 33: Beta Interpretations for Relationships (For Female)

\begin{tabular}{|c|c|c|c|c|c|}
\hline \multicolumn{7}{|c|}{ Coefficients $^{\mathrm{a}}$} & \multirow{2}{*}{ Sig. } \\
\hline \multirow{2}{*}{ Model } & Unstandardized & Standardized & \multirow{2}{*}{$\mathrm{t}$} & \\
\cline { 2 - 5 } & $\mathrm{B}$ & Std. Error & Beta & & \\
\hline Constant & 4.862 & .347 & & 14.017 & .000 \\
\hline TRFLDe & -.228 & .113 & -.229 & -2.021 & .046 \\
\hline TRFLDi & .304 & .100 & .392 & 3.030 & .003 \\
\hline TRSL & .246 & .079 & .333 & 3.121 & .002 \\
\hline \multicolumn{7}{|c|}{ a. Dependent Variable: DM } \\
\hline
\end{tabular}

Based on the above table, the researcher finds the below:

- If the leader will adopt TRFL.De style (Transformational Leadership-Development), then R (Relationships) will be decrease by $22.8 \%$.

- If the leader will adopt TRFL.Di style (Transformational Leadership-Directive), then $\mathrm{R}$ (Relationships) will be increase by $30.4 \%$.

- If the leader will adopt TRSL style (Transactional Leadership), then $\mathrm{R}$ (Relationships) will be increase by $24.6 \%$.

\subsection{Updated Conceptual Framework}

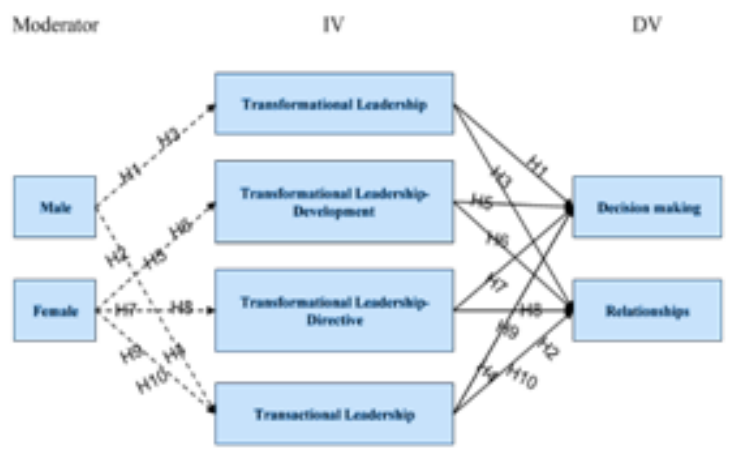

Figure 2: Updated Conceptual Framework

\subsection{Updated and Testing Hypotheses}

1) H1: Male in transformational leadership has an impact on decision making.

Based on table 20, value of $\mathrm{R}$ is 0.509 and $\rho<0.05$.

Based on table 22, $\mathrm{R}^{2}=0.259$.

Based on table 23, $\rho<0.05$.

Based on table 24, $\rho<0.05$.

Based on the above results, it means there is strong relationship between Male, Transformational Leadership and Decision Making, that is supported H1 hypothesis.

2) H2: Male in transactional leadership has an impact on relationships.

Based on table 20, value of $\mathrm{R}$ is 0.014 and $\rho>0.05$.

Based on table 25, $\mathrm{R}^{2}=0.143$.

Based on table 26, $\rho<0.05$.

Based on table 27, $\rho>0.05$.

Based on the above results, it means there no strong significant relationship between Male, Transactional Leadership and Relationships, that is not supported H2 hypothesis.

\section{Volume 10 Issue 1, January 2021 www.ijsr.net}


3) H3: Male in transformational leadership has an impact on Relationship.

Based on table 20, value of $R$ is 0.352 and $\rho<0.05$.

Based on table 25, $\mathrm{R}^{2}=0.143$.

Based on table 26, $\rho<0.05$.

Based on table 27, $\rho<0.05$.

Based on the above results, it means there is strong relationship between Male, Transformational Leadership and Relationships, that is supported $\mathrm{H} 3$ hypothesis.

4) H4: Male in transactional leadership has an impact on decision making.

Based on table 20, value of $R$ is 0.201 and $\rho>0.05$.

Based on table 22, $\mathrm{R}^{2}=0.259$.

Based on table 23, $\rho<0.05$.

Based on table 24, $\rho>0.05$.

Based on the above results, it means there is no strong significant relationship between Male, Transactional Leadership and Decision Making, that is not supported H4 hypothesis.

5) H5: Female in transformational leadership-development has an impact on decision making.

Based on table 21, value of $R$ is 0.474 and $\rho<0.05$.

Based on table 28, $\mathrm{R}^{2}=0.509$.

Based on table $29, \rho<0.05$.

Based on table 30, $\rho>0.05$.

Based on the above results, it means there is no strong significant relationship between Female, Transformational Leadership-Development and Decision Making, that is not supported H5 hypothesis.

6) H6: Female in transformational leadershipdevelopment has an impact on relationships.

Based on table 21, value of $R$ is 0.196 and $\rho<0.05$.

Based on table $31, \mathrm{R}^{2}=0.287$.

Based on table 32, $\rho<0.05$.

Based on table 33, $\rho<0.05$.

Based on the above results, it means there is strong relationship between Female, Transformational LeadershipDevelopment and Relationships, that is supported H6 hypothesis.

7) H7: Female in transformational leadership- directive has an impact on decision making.

Based on table 21, value of $R$ is 0.681 and $\rho<0.05$.

Based on table 28, $\mathrm{R}^{2}=0.509$.

Based on table 29, $\rho<0.05$.

Based on table 34, $\rho<0.05$.

Based on the above results, it means there is strong relationship between Female, Transformational LeadershipDirective and Decision Making, that is supported $\mathrm{H} 7$ hypothesis.

8) H8: Female in transformational leadership- directive has an impact on relationships.

Based on table 21, value of $R$ is 0.445 and $\rho<0.05$.

Based on table $31, \mathrm{R}^{2}=0.287$.

Based on table 32, $\rho<0.05$.

Based on table 33, $\rho<0.05$.

Based on the above results, it means there is strong relationship between Female, Transformational Leadership-
Directive and Relationships, that is supported $\mathrm{H} 8$ hypothesis.

9) H9: Female in transactional leadership has an impact on decision making.

Based on table 21, value of $\mathrm{R}$ is 0.595 and $\rho<0.05$.

Based on table 28, $\mathrm{R}^{2}=0.509$.

Based on table 29, $\rho<0.05$.

Based on table $30, \rho<0.05$.

Based on the above results, it means there is strong relationship between Female, Transactional Leadership and Decision Making, that is supported H9 hypothesis.

10) H10: Female in transactional leadership has an impact on relationships.

Based on table 21, value of $R$ is 0.473 and $\rho<0.05$.

Based on table $31, \mathrm{R}^{2}=0.287$.

Based on table $32, \rho<0.05$.

Based on table 33, $\rho<0.05$.

Based on the above results, it means there is strong relationship between Female, Transactional Leadership and Relationships, that is supported $\mathrm{H} 10$ hypothesis.

\subsection{Hypotheses Test Summary}

Table 34: Hypotheses Test Summary

\begin{tabular}{|c|c|c|}
\hline H & Hypothesis & Result \\
\hline H1 & $\begin{array}{c}\text { Male in transformational leadership has an } \\
\text { impact on decision making }\end{array}$ & Supported \\
\hline H2 & $\begin{array}{c}\text { Male in transactional leadership has an impact } \\
\text { on relationships }\end{array}$ & $\begin{array}{c}\text { Not } \\
\text { Supported }\end{array}$ \\
\hline H3 & $\begin{array}{c}\text { Male in transformational leadership has an } \\
\text { impact on Relationship }\end{array}$ & Supported \\
\hline H4 & $\begin{array}{c}\text { Male in transactional leadership has an impact } \\
\text { on decision making }\end{array}$ & $\begin{array}{c}\text { Not } \\
\text { Supported }\end{array}$ \\
\hline H5 & $\begin{array}{c}\text { Female in transformational leadership- } \\
\text { development has an impact on decision } \\
\text { making }\end{array}$ & $\begin{array}{c}\text { Not } \\
\text { Supported }\end{array}$ \\
\hline H6 & $\begin{array}{c}\text { Female in transformational leadership- } \\
\text { development has an impact on relationships }\end{array}$ & Supported \\
\hline H7 & $\begin{array}{c}\text { Female in transformational leadership- } \\
\text { directive has an impact on decision making }\end{array}$ & Supported \\
\hline H8 & $\begin{array}{c}\text { Female in transformational leadership- } \\
\text { directive has an impact on relationships }\end{array}$ & Supported \\
\hline H9 & $\begin{array}{c}\text { Female in transactional leadership has an } \\
\text { impact on decision making }\end{array}$ & Supported \\
\hline H10 & $\begin{array}{c}\text { Female in transactional leadership has an } \\
\text { impact on relationships }\end{array}$ & Supported \\
\hline
\end{tabular}

\section{Conclusion and Recommendation}

\subsection{Conclusions}

In this research, it was studied which gender is better male or female and which type of leadership favors each gender and its effect on decision making and employees relationships. Female has the highest regression $\left(\mathrm{R}^{2}=\right.$ $50.9 \%$ ) with the decision making. While male has the lowest regression $\left(\mathrm{R}^{2}=14.3 \%\right)$ with the relationships. Female also has regression $\left(\mathrm{R}^{2}=28.7 \%\right)$ with the relationships. While male has regression $\left(\mathrm{R}^{2}=25.9 \%\right)$ with the decision making. When female leaders practice transformational leadership. Directive for decision making and relationships, they pay 
attention to the needs of their supporters, display empathy, and foster personal growth and expression.

Also, according to the results, transactional leadership also has high percent Beta for both decision making and a relationship, that is means female leaders also adopt transactional leadership, but transformational leadership has a larger impact than transactional leadership [78, 79, 80].

On the other hand, male leaders practice transformational leadership for decision making and relationships, they also raising individuals from low levels of need to higher levels of survival [81].

In summary, according to the results of the research, female leaders are more effective and have a huge impact than male leaders on decision making and employees relationships in real estate and construction companies in Istanbul, Turkey.

\subsection{Suggestion and Recommendation for Future Research}

The results of this study demonstrate the effect of transformational and transactional leadership on decision making and relationships in construction and real estate companies; the generalizability of these findings to other companies, such as healthcare services and education companies, is questioned. Will equivalent findings be achieved by an education company with a history of business problems? The environmental and historical background of a company possibly plays a role in the relationship between types of leadership and effectiveness. This topic could be answered by potential field studies. Longitudinal studies could help explain how, over time, the relationship between transformational and transactional leadership and effectiveness works. There will certainly be improvements in how transformational and transactional leadership and leadership effectiveness interconnect over such different periods of a company life cycle as growth, deterioration, mergers, etc. For instance, during the establishment of the company, development, and revitalization phases of a company transformational leadership is most important [82]. In other leadership styles, such as bureaucratic and autocratic leadership, another area that can be exposed to future study is to check if there is a disparity in male and female leadership.

The analysis is also performed much of the time using quantitative methods. Since certain elements of leadership can be evaluated using qualitative methods, both methods should be used to carry out future research.

\section{References}

[1] Gender diversity journey: company good practices / International Labour Office, Bureau for Employers' Activities (ACT/EMP). - Geneva: ILO, 2017.

[2] Grant, Jan. (1998). Women as managers: What they can offer to organizations. Organizational Dynamics, 16(3), 56-63.

[3] Kabacof, R. I., \& Stoffey, R. W. (2001). Age differences in organizational leadership. In 16th
Annual Conference of the Society for Industrial and Organizational Psychology, San Diego, CA.

[4] Karau, S. J., \& Eagly, A. H. (1999). Invited reaction: Gender, social roles, and the emergence of leaders. Human Resource Development Quarterly, 10(4), 321327.

[5] Kim, H. S., \& Shim, S. (2003). Gender-based approach $\mathrm{o}$ the understanding of leadership roles among retail managers. Human Resource Development Quarterly, 14(3), 321-342.

[6] Eagly, A. H., Johannesen-Schmidt, M. C., \& Van Engen, M. L. (2003). Transformational, transactional, and laissez-faire leadership styles: Ameta-analysis comparing women and men.

[7] Mohr, G., \& Wolfram, H. J. (2008). Leadership and effectiveness in the context of gender: The role of leaders' verbal behaviour. British Journal of Management, 19(1), 4-16.

[8] Burke, S., \& Collins, K. M. (2001). Gender differences in leadership styles and management skills. Women in Management Review, 16(5), 244-257.

[9] Powell, G. N. (1990). One more time: Do female and male managers differ? The Executive, 4(3), 68-75.

[10] Rosener, J. B. (1990). Ways women lead. Harvard business review, 68(6), 119-125.

[11] Bass, B. M. (1997). Does the transactionaltransformational leadership paradigm transcend organizational and national boundaries? American psychologist, 52(2), 130.

[12] McKinsey, C. (2007). Women Matter: Gender diversity, a corporate performance driver.

[13] Trinidad, C., \& Normore, A. H. (2005). Leadership and gender: A dangerous liaison? Leadership \& Organization Development Journal, 26(7), 574-590.

[14] Olsson, S., \& Walker, R. (2003). Through a gendered lens? Male and female executives' representations of one another. Leadership \& Organization Development Journal, 24(7), 387-396.

[15] Balasubramanian, P., \& Krishnan, V. R. (2012). Impact of gender and transformational leadership on ethical behaviours. Great Lakes Herald, 6(1), 48-58.

[16] Eagly, A. H., Johannesen-Schmidt, M. C., \& Van Engen, M. L. (2003). Transformational, transactional, and laissez-faire leadership styles: a meta-analysis comparing women and men. Psychological bulletin, 129(4), 569.

[17] Bass, B.M., \& Avolio, B.J. (1994). Shatter the glass ceiling: Women may make better managers. Human Resource Management, 33, 549-560.

[18] Van Engen, M. L., \& Willemsen, T. M. (2004). Sex and leadership styles: A meta-analysis of Research Published in the 1990s. Psychological Reports, 94 (1), 3-18.

[19] Gregory, A. (1990). Three theoretical perspectives concerning women in management Journal of Business Ethics, 9, 257- 266.

[20] Eagly, A. H., \& Karau, S. J. (1991). Gender and emergence of leaders: Ameta analysis, Journal of Personality and Social Psychology, 60, 685-710.

[21] Korabik, K., \& Ayman, R. (1989). Should women managers have to act like men? Journal of Management Development, 8(6), 23-32. 
[22] Smith PB, Wang ZM (1996). Chinese leadership and organizational structure. In $\mathrm{MH}$, Bond. eds. The handbook of Chinese psychology. Hong Kong: Oxford University Press.

[23] Hosftede G (1980). Culture's consequences: International differences inwork related values. Beverly Hill, CA: Sage.

[24] Smith PB, Bond MH (1993). Social psychology across cultures: Analysis and perspectives. Needham, MA: Allyn and Bacon.

[25] Gelfand MJ, Erez M, Aycan Z (2007). Cross-cultural organizational behavior. Annu. Rev. Psychol., 58: 479514.

[26] Eagly AH (1987). Sex differences in social behavior: A social-role Interpretation. Erlbaum, NJ: Hillsdale.

[27] Eagly AH, Wood W, Diekman AB (2000). Social role theory of sex differences and similarities: A current appraisal. In Eckes T, Trautner HM (Eds.). The developmental social psychology of gender. Mahwah, NJ: Lawrence Erlbaum Associates. pp. 123-174.

[28] Eagly AH, Karau SJ (2002). Role congruity theory of prejudice toward female leaders. Psychol. Rev., 109(3): 573-598.

[29] Eagly AH, Makhijani MG, Klonsky BG (1992). Gender and the evaluation of leaders: A meta-analysis. Psychol. Bull. 111(1), 18(1): 39-50.

[30] Vecchio RP, Bullis RC (2001). Moderators of the influence of supervisor-subordinate similarity on subordinate outcomes. J. Appl. Psychol., 86(5): 884896.

[31] Brenner O, Tomkiewicz J, Schein VE (1989). The relationship betweens ex role stereotypes and requisite management characteristics revisited. Acad. Manag. J., 32(3): 662-669.

[32] Deal JJ, Stevenson MA (1998). Perceptions of female and male managers in the 1990s: Plus ça change. Sex Roles, 38(3): 287-300.

[33] Powell GN, Butterfield DA (1989). The "good manager": Did androgynyfare better in the 1980s? Group Org. Stud., 14(2): 216-233.

[34] Powell GN, Butterfield DA, Parent JD (2002).Gender and managerial stereotypes: Have the times changed? J. Manag., 28(2): 177-193.

[35] Moss, J. and Jensrud, Q. 1995. “Gender, leadership and vocational education". Journal of Industrial Teacher Education, Vol. 33 (1): 6-23.

[36] Blake, R. and Mouton, J. 1964. The Managerial Grid: Key Orientations for Achieving Production Through People, Houston, TX: Gulf Publishing.

[37] Hersey, P. and Blanchard, K. H. 1988. Management of Organizational Behaviour. Englewood Cliffs, NJ:Prentice-Hall.

[38] Eagly, A. H. and Johnson, B. T. 1990. "Gender and leadership style: a meta-analysis". Psychological Bulletin, Vol. 108: 233-256.Self-identity and Work. New York: Oxford University Press.

[39] Park, D. 1996. "Gender role, decision style and leadership style". Women in Management Review, Vol. $11(8): 13-17$.

[40] Avolio, B. J. and Howell, J. M. 1992. "The impact of leader behaviour and leader-follower personality match on satisfaction and unit performance", in Clarke, K. E. Clarke, M. B., and CampbellD. R. (Eds.). Impact of Leadership, Greensboro, NC, The Center for Creative Leadership.

[41] Bass, B. M. 1985. Leadership and Performance Beyond Expectations. New York, NY: Free Press.

[42] Hater, J. J. and Bass, B. M. 1988. "Supervisors evaluations and subordinates' perceptions of transformational leadership". Journal of Applied Psychology, Vol. 73: 695-702.

[43] Neumann, Y. and Neumann, E. F. 1999. "The president and the college bottom line: the role of strategic leadership styles". The International Journal of Educational Management, Vol. 13 (2): 73-81.

[44] Ramsden, P. 1998. Learning to Lead in Higher Education. New York: Routledge.

[45] Seltzer, J and Bass, B. M. 1990. "Transformational leadership: beyond initiation and consideration". Journal of Management, Vol. 16: 693-703.

[46] Bryman, A. 1992. Charisma and Leadership in Organizations. London: Sage.

[47] Sullivan, E. and Decker, P.P. (2001). Effective Leadership and Management in Nursing. Image Credit: Daveeza, flickr.com

[48] Nayab, N. (2010). Characteristics of Transformational Leadership. http://www.brighthubinc./March 23, 2011.

[49] Saeed, T., Almas, S., Anis-ul-Haq, M., Niazi, G.S.K. (2014), Leadership styles: Relationship with conflict management styles. International Journal of Conflict Management, 25(3), 214-225.

[50] Bass, B. M. (1997). Does the transactionaltransformational leadership paradigm transcend organizational and national boundaries? American Psychologist, 52, 130-139.

[51] Druskat, V.U. (1994). Gender and Leadership Style: Transformational and Transactional Leadership in The Roman Catholic Church. Leadership Quarterly, 5(2), 99-199.

[52] Kreitner, R. \& Kinicki, A. (2008). Organizational Behaviour (8the ed.). New York: McGrawHill.

[53] Bass, B.M. and Avolio, B.J. (1994), Improving Organizational Effectiveness Through Transformational Leadership, Sage, Thousand Oaks, CA.

[54] Bass, B.M., Avolio, B.J. and Atwater, L. (1996). The Transformational and Transactional Leadership of Men and Women. Applied Psychology: An International Review, Vol. 45, 5-34.

[55] Aydogdu, S., \& Asikgil, B. (2011). The effect of transformational leadership behaviour on organizational culture: An application in pharmaceutical industry. International Review of Management and Marketing, 1(4), 65.

[56] Covey (2007). The transformational leadership report: Developing tomorrow's transformational leaders today. Accessed on June 21, 2011 from www.transformationalleadership.net

[57] Mullins, L. (2005). Management and Organisational Behaviour, 7th Ed. London: Prentice Hall.

[58] Bass, B.M. (1990). From Transactional to Transformational Leaders: Learning to Share the Vision. Organizational Dynamics, 18(3), 19-31.

[59] Lowe, K.B., Kroeck, K.G., \& Sivasubramaniam, N. (1996). Effectiveness Correlates of Transformational and Transactional Leadership: A Meta-Analytic 
Review of The MLQ Literature. Leadership Quarterly 7(3), 385-425.

[60] Bass, B. M., \& Avolio, B. J. (2004). Manual for the multifactor leadership questionnaire (MLQ - Form 5X). CA, Redwood City: Mindgarden.

[61] Sosik, J. J., \& Jung, D. I. (2010). Full range leadership development: Pathways for people, profit and planet. New York: Routledge.

[62] Bass, B., \& Stogdill, R. (1990). Bass and Stogdill's handbook of leadership: Theory research and managerial applications. New York: Free Press.

[63] Cooper, J. F. \& Nirenberg, J. (2004). Leadership effectiveness. Encyclopedia of leadership (pp. 845854). Thousand Oaks, CA: SAGE Publications.

[64] Yaqoub, H. A. A. (2018). Effects of Gender on Leadership. California university of Pennsylvania.

[65] Grunig, J.E., \& Hon, L. (1999). Guidelines for Measuring Relationships in PublicRelations. The Institute for Public Relations Commission on PR Measurement and Evaluation, 1-40.

[66] Kurt, A., \& Zehir, C. (2016). "The relationship between cost leadership strategy, total quality management applications and financial performance", Doğuş Üniversitesi Dergisi, 17 (1) 2016, 97-110.

[67] Collis, J. and Hussey, R. (2003), Business research, 2nd ed, Palgrave MacMillan.

[68] Czaja, R. and Blair, J. (2005) Designing Surveys: A Guide to Decisions and Procedures (second edition). Thousand Oaks: Sage, Pine Forge Press.

[69] Creswell, J. W. (2014). Research Design: Qualitative, Quantitative and Mixed Methods Approaches (4th ed.). Thousand Oaks, CA: Sage.

[70] Kumar, J. (2005). Research methodology: A step-bystep guide for beginners (2nd ed.). London: Sage.

[71] Bass, B. M. \& Avolio, B. J. (1997). Full range leadership development - Manual for the multifactor leadership questionnaire. Redwood City, CA: Mind Garden.

[72] Bass, B. M., Avolio, B. J., Jung, D. I., \& Berson, Y. (2003). Predicting Unit Performance by Assessing Transformational and Transactional Leadership. Journal of Applied Psychology, 88, 207-218.

[73] Alsayed, A. K., Motaghi, M. H. ve Osman, I. B. (2012). The use of the multifactor leadership questionnaire and communication satisfaction questionnaire in Palestine: A research note. International Journal of Scientific and Research Publications, 2(11).

[74] Paracha, M. U., Qamar, A., Mirza, A., Hassan, I. and Waqas, H. (2012). Impact of leadership style(transformational \& transactional leadership) on employee performance \& mediating role of job satisfaction: Study of private school (educator) in Pakistan. Global Journal of Management and Business Research, 12(4), 55-64.

[75] Cerny, B. A., \& Kaiser, H. F. (1977). A study of a measure of sampling adequacy for factor-analytic correlation matrices. Multivariate Behavioural Research, 12(1), 43-47.

[76] Kaiser, H. F. "An index of factorial simplicity, Psychometrics 39: 31-36." (1974).

[77] Pallant, J. (2007). SPSS survival manual, 3rd. Edition. McGrath Hill, 15.
[78] Northouse, P. G. (2001). Leadership: Theory and practice (2nd ed.). Sage Publications, Inc.

[79] Dvir, T., D. Eden, B. J. Avolio, \& B. Shamir. (2002). Impact of transformational leadership on follower development and performance: A field experiment. Academy of Management Journal, 45(4), 735-744.

[80] Waldman, D. A., Ramirez, G. G., House, R. J., \& Puranam, P. 2001. Does leadership matter?:CEO leadership attributes under conditions of perceived environmental uncertainty. Academy of Management Journal, 44: 134-143.

[81] Yukl, G. (1989). Leadership in organizations, second edition. Englewood Cliffs, NJ: Prentice-Hall.

[82] Baliga, B. R., Dachler, H. P., \& Schriesheim, C. A. (1988). Emerging leadership vistas (pp. 85-88). J. G. Hunt (Ed.). Lexington, MA: Lexington Books. URL1: $<$ https://bilgibankasi.ito.org.tr/en/databank/company-statics/number-of-activecompanies $>$ (Accessed on 13/10/2020)

\section{Author Profile}

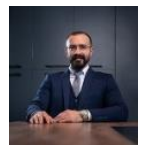

Basel Dwiri. Received the bachelor's degree in civil engineering from Al-Ahliyya Amman University, Amman, Jordan, and master's degree in Business Administration (MBA) from Istanbul Aydin University, Istanbul, Turkey. CEO \& Founder at EserEd, a company specialized in student services and educational consultations, Istanbul, Turkey.

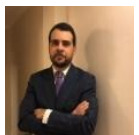

Dr. Kağan Okatan. He worked as a manager in the field of Information Technologies for many years. $\mathrm{He}$ led large-scale digital transformation projects. $\mathrm{He}$ holds a doctorate in business administration and a master's degree in information technology. He is a university lecturer and research and development projects consultant. He has focused mainly on management information systems in the fields of knowledge-based management and innovation management of organizations. 